\title{
Pharmacokinetics and Bioavailability of Hapepunine in Mice by Ultra-Performance Liquid Chromatography-Tandem Mass Spectrometry
}

\author{
Lianguo Chen ${ }^{1}$, Qingwei Zhang ${ }^{2}$, Yijing Lin $^{2}$, Xiaojie $\mathrm{Lu}^{2}$, Zuoquan Zhong ${ }^{2}$, Jianshe $\mathrm{Ma}^{3}$, \\ Congcong $\mathrm{Wen}^{3^{*}}$ and Cheng Ding ${ }^{4 *}$ \\ ${ }^{\prime}$ Department of Pharmacy, Wenzhou People's Hospital, Wenzhou 325000, China \\ 'Shanghai Institute of Pharmaceutical Industry, China State Institute of Pharmaceutical Industry, Shanghai 201203, China \\ ${ }^{3}$ Laboratory Animal Center, Wenzhou Medical University, Wenzhou 325035, China \\ ${ }^{4}$ The First Affiliated Hospital of Wenzhou Medical University, Wenzhou 325000, China
}

Received: 22 October 2018; accepted: 14 January 2019

\begin{abstract}
An ultra-performance liquid chromatography-tandem mass spectrometry (UPLC-MS/MS) method was established to determine the hapepunine in mouse blood, and the pharmacokinetics of hapepunine after intravenous $(1.0 \mathrm{mg} /$ $\mathrm{kg}$ ) and intragastric $(2.5,5$, and $10 \mathrm{mg} / \mathrm{kg}$ ) administrations was studied. Delavinone was used as an internal standard. The UPLC ethylene bridged hybrid (BEH) C18 column was used for chromatographic separation. The mobile phase consisted of acetonitrile and $0.1 \%$ formic acid with a gradient elution flow rate of $0.4 \mathrm{~mL} / \mathrm{min}$. Multiple reaction monitoring (MRM) mode was used for quantitative analysis of hapepunine in electrospray ionization (ESI) positive interface. Proteins from mouse blood were removed by acetonitrile precipitation. The verification method was established in accordance with the US Food and Drug Administration (FDA) bioanalytical method validation guidelines. In the concentration range of $1-1000 \mathrm{ng} / \mathrm{mL}$, the hapepunine in the mouse blood was linear $\left(r^{2}>0.995\right)$, and the lower limit of quantification was $1.0 \mathrm{ng} / \mathrm{mL}$. In the mouse blood, the intra-day precision coefficient of variation $(\mathrm{CV})$ was less than $12 \%$, the inter-day precision $\mathrm{CV}$ was less than $14 \%$. The accuracy ranged from $91.7 \%$ to $109.3 \%$. The average recovery was higher than $76.7 \%$, and the matrix effect was between $86.0 \%$ and $106.4 \%$. The UPLC-MS/MS method was sensitive, rapid, and selective and was successfully applied to the pharmacokinetic study of hapepunine in mice. The absolute bioavailability of hapepunine was $22.0 \%$.
\end{abstract}

Keywords: hapepunine, pharmacokinetics, bioavailability, mouse, UPLC-MS/MS

\section{Introduction}

Fritillaria species was one of the important drug sources often used for depressing coughs $[1,2]$. Some steroidal alkaloids of the ceveratrum and jerveratrum alkaloid groups were isolated [3]. The bulbs of $F$. maximowiczii (Rinyou-Baimo) grown in northeast China were expected to be a substitute for the bulbs of other Fritillaria species, F. thunbergii (SetuBaimo), cirrhosa, unibracteata, and taipaiensis (Sen-Baimo), since pharmacological tests provided evidence that they also could be used to treat coughs $[4,5]$. Therefore, the chemical constituents of these species were investigated, and hapepunine was one of the main active components in maximowiczii. To better understand the pharmacology of hapepunine, it was necessary to investigate its pharmacokinetics. Pharmacokinetic study was a discipline that quantitatively investigates the absorption, distribution, metabolism, and excretion of drugs in vivo $[6,7]$. Therefore, it was necessary to establish an analytical method to monitor the concentration of hapepunine.

To the best of our knowledge, the pharmacokinetics of hapepunine had not been reported. In this paper, an ultra-performance liquid chromatography-tandem mass spectrometry (UPLC-MS/MS) method was established to determine hapepunine in mouse blood, the pharmacokinetics of hapepunine

*Author for correspondences: bluce494949@163.com (C.W.), charles0022@sina.com (C.D.). after intravenous and intragastric administration was studied, and the absolute bioavailability was obtained.

\section{Experimental}

Chemicals and Animals. Hapepunine (purity $>98 \%$, Figure 1A) and delavinone (internal standard, purity $>98 \%$, Figure 1B) were purchased from Chengdu Mansite Pharmaceutical Co., Ltd. Chromatographically pure acetonitrile and methanol were purchased from Merck Co., Ltd. (Darmstadt, Germany). Ultrapure water was prepared using a Millipore Milli-Q purification system (Bedford, MA, USA). Institute of Cancer Research (ICR) mice (body weight 20-22 g) were purchased from the Animal Experimental Center of Wenzhou Medical University.

Instrument and Conditions. ACQUITY I-Class UPLC and XEVO TQS-micro triple quadrupole mass spectrometers (Waters Corp., Milford, MA, USA) were used for the determination of hapepunine in mouse blood. Masslynx 4.1 software (Waters Corp.) was used for data acquisition and instrument control.

The column was UPLC ethylene bridged hybrid (BEH) $\mathrm{C} 18(2.1 \mathrm{~mm} \times 50 \mathrm{~mm}, 1.7 \mu \mathrm{m})$, and the column temperature was set to $30{ }^{\circ} \mathrm{C}$. The mobile phase consisted of acetonitrile and $0.1 \%$ formic acid with a gradient elution at a flow rate of $0.4 \mathrm{~mL} / \mathrm{min}$ and an elution time of $4 \mathrm{~min}$. The gradient elution conditions were as follows: $0-0.2 \mathrm{~min}$, acetonitrile $10 \%$; $0.2-1.5 \mathrm{~min}$, acetonitrile $10 \%-85 \% ; 1.5-2.0 \mathrm{~min}$, acetonitrile

This is an open-access article distributed under the terms of the Creative Commons Attribution-NonCommercial 4.0 International License (https://creativecommons.org/licenses/by-nc/4.0/), which permits unrestricted use, distribution, and reproduction in any medium for non-commercial purposes, provided the original author and source are credited, a link to the CC License is provided, and changes - if any - are indicated. 


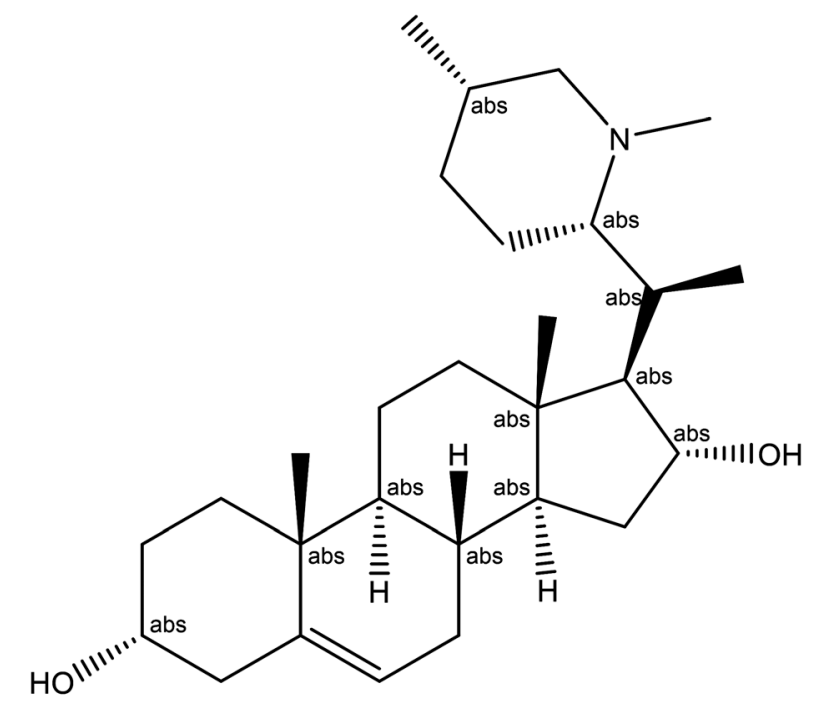

(A)

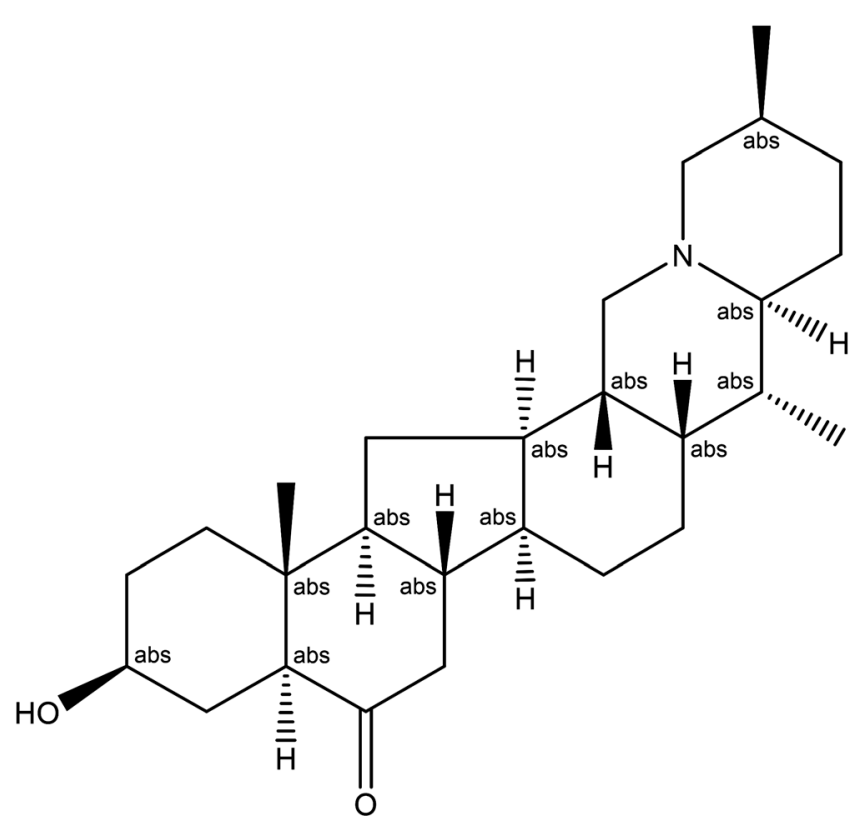

(B)

Figure 1. Chemical structure of hapepunine (A) and delavinone (internal standard, B)

$85 \% ; 2.0-2.5 \mathrm{~min}$, acetonitrile $85 \%-10 \%$; and $2.5-4.0 \mathrm{~min}$, acetonitrile $10 \%$.

Nitrogen was used as the desolvation gas $(800 \mathrm{~L} / \mathrm{h})$ and the cone gas $(50 \mathrm{~L} / \mathrm{h})$. The capillary voltage was set to $2.0 \mathrm{kV}$, the ion source temperature was $150{ }^{\circ} \mathrm{C}$, and the desolvation temperature was $400{ }^{\circ} \mathrm{C}$. The multiple reaction monitoring (MRM) model was quantitatively analyzed for hapepunine $\mathrm{m} / \mathrm{z}$ $430.5 \rightarrow 111.9$ and internal standard $\mathrm{m} / \mathrm{z} 414.4 \rightarrow 98.1$ in electrospray ionization (ESI) positive interface (Figure 2).

Reference Solution Preparation. Stock solutions of hapepunine $(1.0 \mathrm{mg} / \mathrm{mL})$ and delavinone $(1.0 \mathrm{mg} / \mathrm{mL})$ were prepared with methanol-water (50:50), respectively. A series of concentration working solutions $(10,30,50,200,500,1800$, 2000, 5000, 9000, and $10,000 \mathrm{ng} / \mathrm{mL}$ ) of hapepunine was prepared by diluting a hapepunine stock solution with methanol. A solution of the internal standard delavinone $50 \mathrm{ng} /$ $\mathrm{mL}$ in acetonitrile was prepared by diluting stock solution of delavinone with acetonitrile. All solutions were stored at $4{ }^{\circ} \mathrm{C}$.

Standard Curve Preparation. The blank mouse blood was mixed with an appropriate amount of standard working

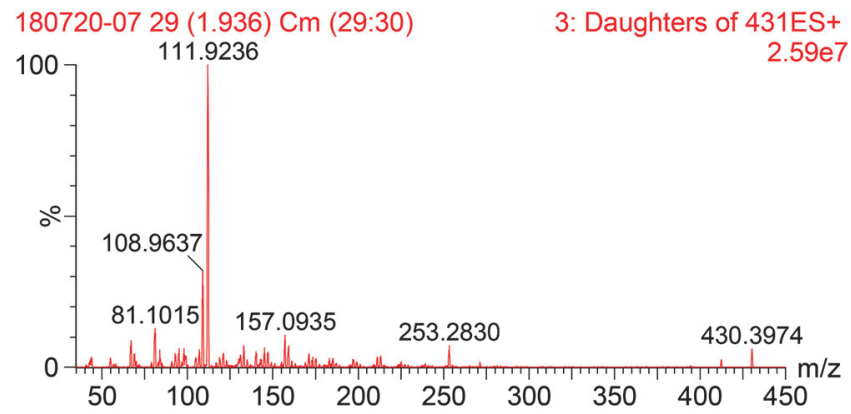

(A)

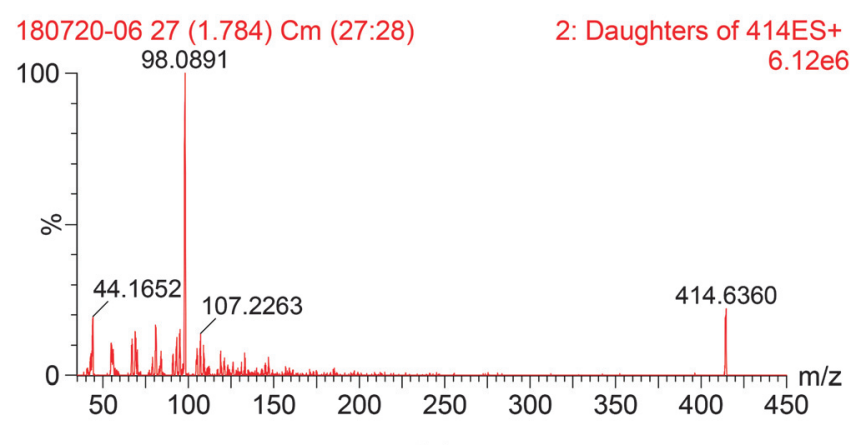

(B)

Figure 2. Mass spectrum of hapepunine (A) and delavinone (internal standard, B)

solution to prepare the blood standard curve of hapepunine, and the concentration of hapepunine in the blood of mice was $1,5,20,50,200,500$, and $1000 \mathrm{ng} / \mathrm{mL}$. The standard curve ranges from 1 to $1000 \mathrm{ng} / \mathrm{mL}$. Quality-control (QC) samples were prepared in the same manner as the standard curve, with 4 blood concentrations $(1,3,180$, and $900 \mathrm{ng} / \mathrm{mL})$.

Sample Processing. The $20 \mu \mathrm{L}$ blood sample was added to a $1.5-\mathrm{mL}$ Eppendorf tube, and then $100 \mu \mathrm{L}$ acetonitrile (containing $50 \mathrm{ng} / \mathrm{mL}$ delavinone) was added, vortexed for $1.0 \mathrm{~min}$, and centrifuged at $4{ }^{\circ} \mathrm{C}$ for $1 \mathrm{~min}$ at $13,000 \mathrm{rpm}$. The $80 \mu \mathrm{L}$ of the supernatant was taken into the inner tube of the sample bottle, and $2 \mu \mathrm{L}$ was injected into UPLC-MS/MS for analysis.

Method Validation. The verification method was established in accordance with the US Food and Drug Administration (FDA) bioanalytical method validation guidelines. Validation projects included selectivity, matrix effects, linearity, precision, accuracy, recovery, and stability [8-12].

Pharmacokinetic Study. About $8.0 \mathrm{mg}$ hapepunine was dissolved in purified water containing $0.01 \% \mathrm{HCl}$ and prepared into a $1.0 \mathrm{mg} / \mathrm{mL}$ drug solution, freshly prepared before the experiment. Twenty-four mice were randomly divided into 4 groups, one group was for intravenous administration $(1.0 \mathrm{mg} / \mathrm{kg})$, and other three groups were for intragastric administration $(2.5,5.0$, and $10.0 \mathrm{mg} / \mathrm{kg})$, with 6 rats in each group. Then, $20 \mu \mathrm{L}$ blood was obtained in a $1.5 \mathrm{~mL}$ Eppendorf tube from tail vein, $5 \mathrm{~min}, 0.5,1,1.5,2,3$, 4 , and $8 \mathrm{~h}$ after intravenous or intragastric administration in mice, and was frozen at $-20{ }^{\circ} \mathrm{C}$.

DAS 2.0 software (China Pharmaceutical University) was used to analyze pharmacokinetic parameters. The formula for bioavailability was absolute bioavailability = intragastric administration AUC/intravenous AUC $\times 100 \%$.

\section{Results and Discussion}

Method Optimization. ESI positive and negative selections were often evaluated in methodological studies [13-16]. 

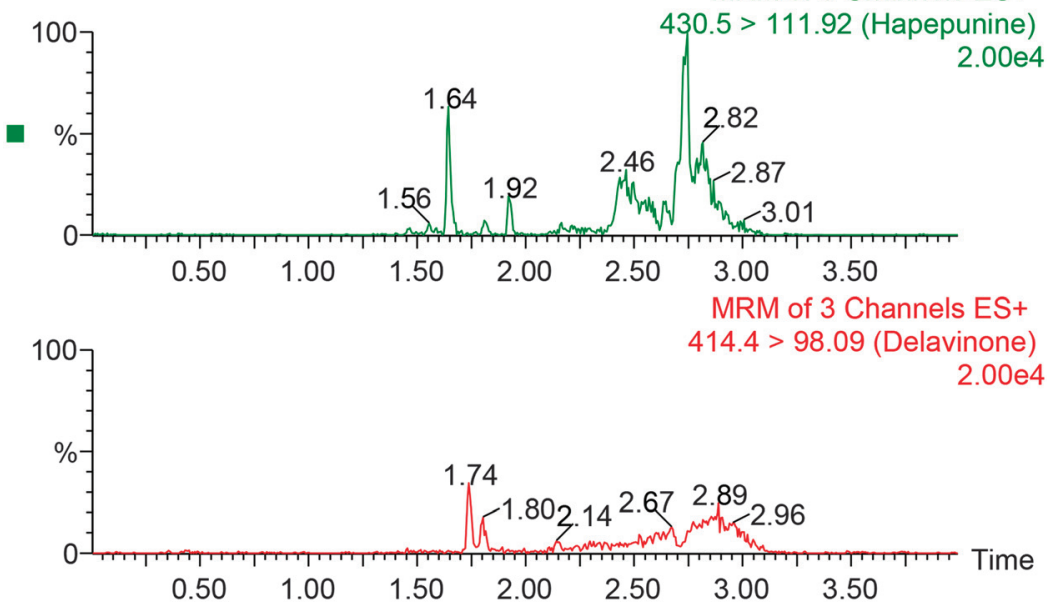

(A)

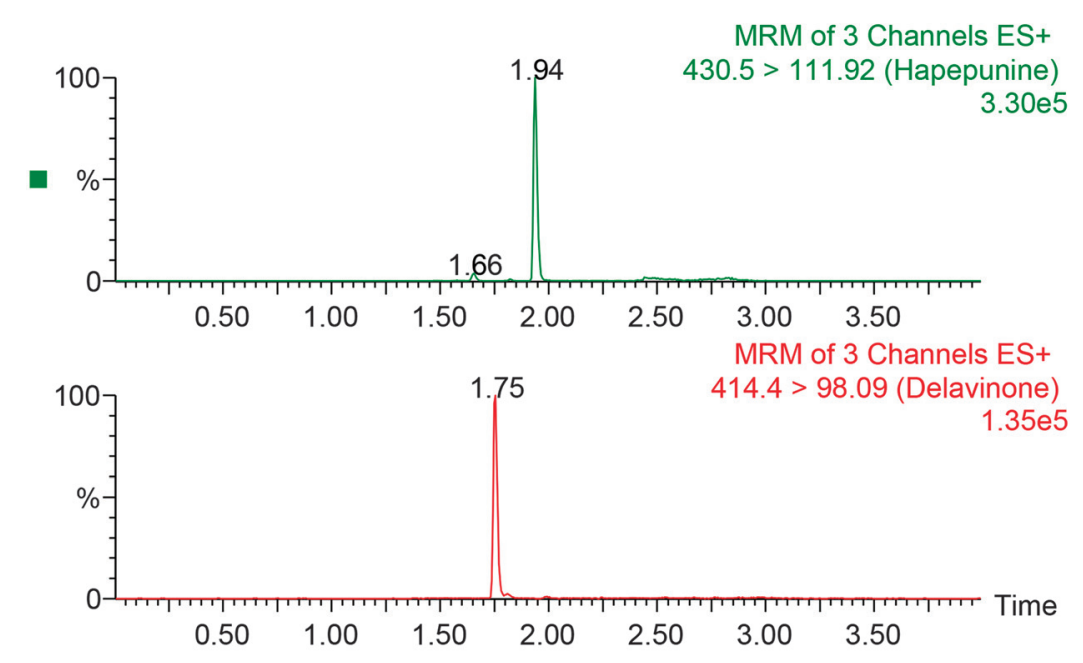

(B)

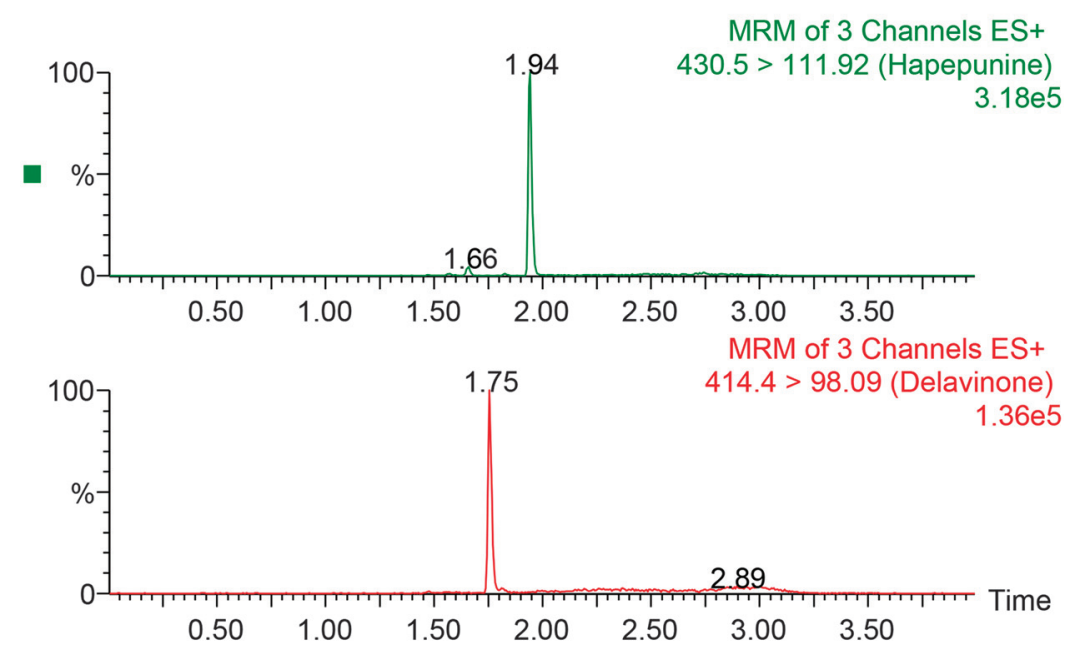

(C)

Figure 3. UPLC-MS/MS of hapepunine and delavinone (internal standard) in mouse blood. (A) Blank blood, (B) blank blood spiked hapepunine $(5 \mathrm{ng} / \mathrm{mL})$ and internal standard $(50 \mathrm{ng} / \mathrm{mL})$, and $(\mathrm{C})$ a mouse blood sample

Hapepunine was an alkaline compound, more suitable for ESI positive detection. Our experiments verified that ESI positive ion mode was more sensitive than the negative one. We optimized the ionization conditions of hapepunine; the highest abundance of fragment ion was $m / z 111.9$, and the highest abundance of internal standard fragment was $\mathrm{m} / \mathrm{z}$ 98.1. Therefore, the quantitative analysis was carried out by selecting hapepunine $\mathrm{m} / \mathrm{z} 430.5 \rightarrow 111.9$ (cone hole voltage of $30 \mathrm{~V}$ and collision voltage of $22 \mathrm{~V}$ ) and internal standard $\mathrm{m} / \mathrm{z}$ $414.4 \rightarrow 98.1$ (cone hole voltage $32 \mathrm{~V}$ and collision voltage $25 \mathrm{~V})$.

Liquid chromatography conditions separate the endogenous interfering substances as much as possible from the analyte with internal standard retention time [17-20]. We tried 
Table 1. Accuracy, precision, matrix effect, and recovery of hapepunine in the mouse blood

\begin{tabular}{|c|c|c|c|c|c|c|}
\hline \multirow{2}{*}{$\begin{array}{l}\text { Concentration } \\
(\mathrm{ng} / \mathrm{mL})\end{array}$} & \multicolumn{2}{|c|}{ Accuracy (\%) } & \multicolumn{2}{|c|}{ Precision $(\mathrm{CV} \%)$} & \multirow{2}{*}{$\begin{array}{c}\text { Matrix } \\
\text { Effect } \\
(\%)\end{array}$} & \multirow{2}{*}{$\begin{array}{c}\text { Recovery } \\
(\%)\end{array}$} \\
\hline & $\begin{array}{c}\text { Intra- } \\
\text { day }\end{array}$ & $\begin{array}{c}\text { Inter- } \\
\text { day }\end{array}$ & $\begin{array}{l}\text { Intra- } \\
\text { day }\end{array}$ & $\begin{array}{c}\text { Inter- } \\
\text { day }\end{array}$ & & \\
\hline 1 & 94.7 & 91.7 & 11.2 & 13.7 & 4.9 & $85.5 \pm 5.2$ \\
\hline 3 & 104.8 & 109.3 & 7.7 & 7.2 & 87.1 & $92.0 \pm 5.3$ \\
\hline 180 & 103.1 & 93.8 & 6.8 & 8.8 & $101.0 \pm 4.6$ & $81.9 \pm 2.4$ \\
\hline 900 & 97.4 & 103.5 & 3.3 & 4.8 & $106.4 \pm 9.6$ & $76.7 \pm 6.9$ \\
\hline
\end{tabular}

acetonitrile $-0.1 \%$ formic acid, acetonitrile- $10 \mathrm{mmol} / \mathrm{L}$ ammonium acetate (containing $0.1 \%$ formic acid), methanol- $0.1 \%$ formic acid, methanol-10 mmol/L ammonium acetate (containing $0.1 \%$ formic acid), and using gradient elution. It was
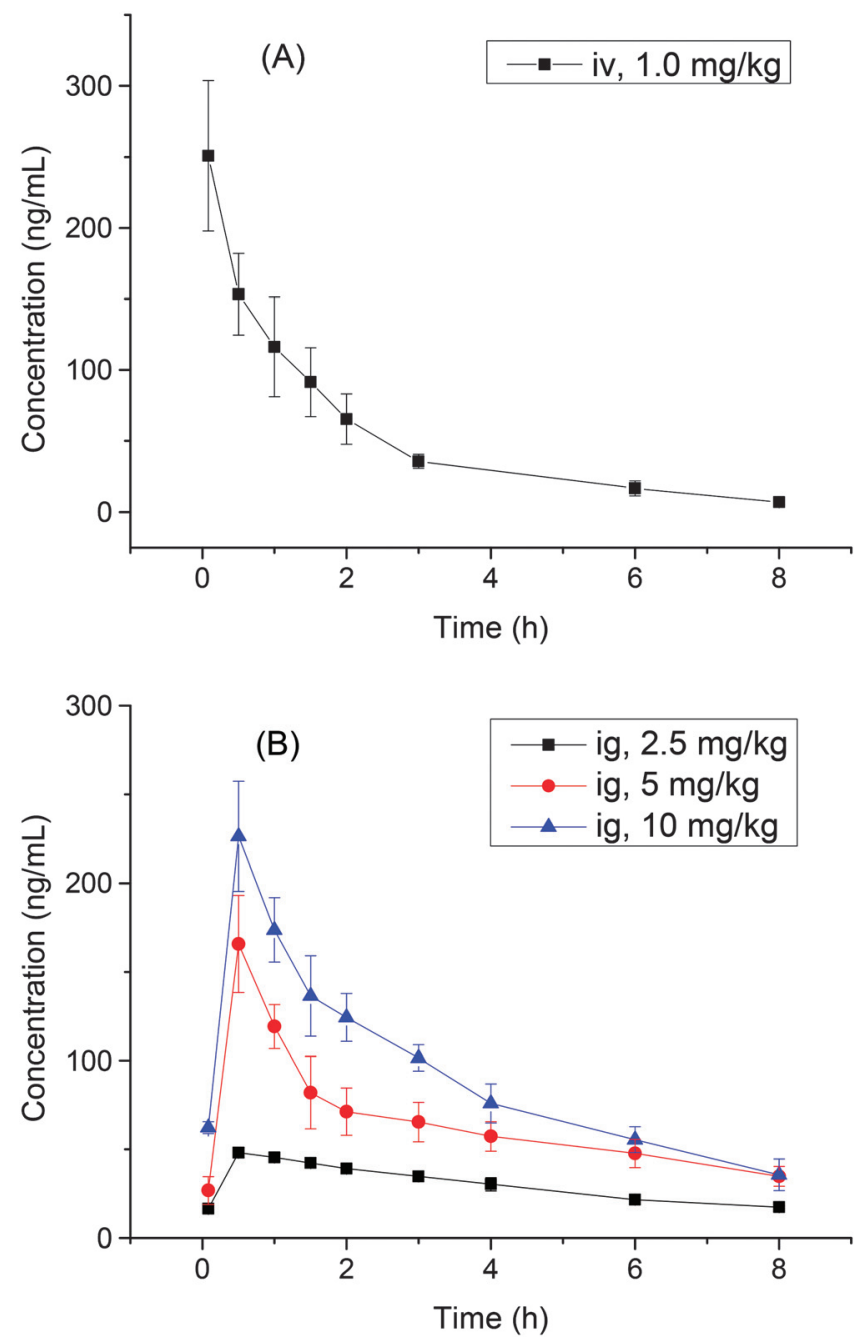

Figure 4. Time-blood concentration curve of hapepunine in mouse blood after intravenous $(1.0 \mathrm{mg} / \mathrm{kg})$ and oral $(2.5,5$, and $10 \mathrm{mg} / \mathrm{kg})$ administrations found that acetonitrile- $0.1 \%$ formic acid gave the most satisfactory peak shape and retention time. At the same time, different columns were compared, and finally, the Waters Acquity UPLC BEH C18 $(2.1 \mathrm{~mm} \times 100 \mathrm{~mm}, 1.7 \mu \mathrm{m})$ column was selected. Therefore, the BEH C18 $(2.1 \mathrm{~mm} \times 50 \mathrm{~mm}$, $1.7 \mu \mathrm{m}$ ) column with acetonitrile $-0.1 \%$ formic acid as the mobile phase was used in this work.

Selection of internal standard was very important in the establishment of the method $[21,22]$. In this study, delavinone, which had a similar structure to hapepunine, was selected as an internal standard. Results showed that the behavior of chromatographic retention time and the ionization mass spectrometry was similar and met the requirements of internal standard for UPLC-MS/MS analysis.

UPLC-MS/MS was applied to the quantitative detection of hapepunine in mouse blood, which was faster and sensitivity than traditional high-performance liquid chromatography (HPLC). It needed only 4 min to complete the analysis of the blood sample, which saved a lot of time and solvent. In addition, for LLOQ $(1.0 \mathrm{ng} / \mathrm{mL})$ was relatively low, which could be used to determine lower blood concentrations at the last sampling time point.

Method Validation. The retention times of hapepunine and internal standard were 1.94 and $1.75 \mathrm{~min}$ in Figure 3, respectively. No obvious impurities and endogenous substances interfered with the detection, indicating that the selectivity of the method was good.

The standard curve equation of hapepunine in the mouse blood was $Y=0.0104 C+0.0123, r^{2}=0.9998$, where Y represents the ratio of the peak area of the hapepunine and the internal standard, and $C$ represents the concentration of hapepunine in mouse blood. The LLOQ in mouse blood was $1.0 \mathrm{ng} / \mathrm{mL}$, with a signal-to-noise ratio of 8 . The limit of detection (LOD) was $0.3 \mathrm{ng} / \mathrm{mL}$, with a signal-to-noise ratio of 3 .

As shown in Table 1, the intra-day precision coefficient of variation $(\mathrm{CV})$ was less than $12 \%$; the inter-day precision $\mathrm{CV}$ was less than $14 \%$. The accuracy ranged from $91.7 \%$ to $109.3 \%$, and the average recovery was higher than $76.7 \%$. The matrix effect was between $86.0 \%$ and $106.4 \%$. These data met the pharmacokinetic study requirements of hapepunine.

The mouse blood was stored at room temperature for $2 \mathrm{~h}$ and $-20{ }^{\circ} \mathrm{C}$ for 30 days, and subjected to freeze-thaw stability test; the variation of hapepunine was within $\pm 14 \%$ and $C V$ was less than $12 \%$, indicating that the stability of hapepunine was acceptable.

Pharmacokinetics Study. In this study, the UPLC-MS/MS method was used to study the pharmacokinetics of hapepunine after intravenous and intragastric administrations. The concentration-time curve of hapepunine was shown in Figure 4. The non-compartmental model was fitted to the main pharmacokinetic parameters, as shown in Table 2. As could be seen from Table 2, the absolute bioavailabilities of the hapepunine $(2.5,5$, and $10 \mathrm{mg} / \mathrm{kg})$ were $23.3 \%, 25.1 \%$, and $17.7 \%$, and the average absolute bioavailability was

Table 2. Main pharmacokinetic parameters of hapepunine in mice

\begin{tabular}{lccccc}
\hline Parameters & Unit & IV $(1.0 \mathrm{mg} / \mathrm{kg})$ & IG $(2.5 \mathrm{mg} / \mathrm{kg})$ & IG $(5 \mathrm{mg} / \mathrm{kg})$ & $\mathrm{IG}(10 \mathrm{mg} / \mathrm{kg})$ \\
\hline $\mathrm{AUC}_{(0-t)}$ & $\mathrm{ng} / \mathrm{mL}{ }^{*} \mathrm{~h}$ & $413.0 \pm 53.2$ & $240.3 \pm 5.0$ & $518.3 \pm 60.8$ & $729.6 \pm 44.3$ \\
$\mathrm{AUC}_{(0-\infty)}$ & $\mathrm{ng} / \mathrm{mL} * \mathrm{~h}$ & $433.8 \pm 54.5$ & $334.8 \pm 39.6$ & $926.0 \pm 226.7$ & $896.4 \pm 100.7$ \\
$\mathrm{MRT}_{(0-t)}$ & $\mathrm{h}$ & $1.85 \pm 0.24$ & $3.37 \pm 0.04$ & $3.20 \pm 0.09$ & $2.93 \pm 0.07$ \\
$\mathrm{MRT}_{(0-\infty)}$ & $\mathrm{h}$ & $2.26 \pm 0.38$ & $6.40 \pm 1.19$ & $9.75 \pm 2.76$ & $4.74 \pm 0.67$ \\
$t_{1 / 2 z}$ & $\mathrm{~h}$ & $1.8 \pm 0.4$ & $4.2 \pm 0.9$ & $7.0 \pm 2.0$ & $3.3 \pm 0.5$ \\
$\mathrm{CL}_{z / F}$ & $\mathrm{~h} / \mathrm{h} / \mathrm{kg}$ & $2.3 \pm 0.3$ & $7.5 \pm 0.9$ & $5.7 \pm 1.4$ & $11.3 \pm 1.2$ \\
$V_{z / F}$ & $\mathrm{~L} / \mathrm{kg}$ & $6.2 \pm 1.8$ & $45.2 \pm 5.0$ & $55.0 \pm 9.7$ & $52.2 \pm 4.6$ \\
$C_{\max }$ & $\mathrm{ng} / \mathrm{mL}$ & $250.8 \pm 53.0$ & $48.1 \pm 2.8$ & $165.7 \pm 27.4$ & $226.3 \pm 30.9$ \\
Bioavailability & & & $23.3 \%$ & $25.1 \%$ & $17.7 \%$
\end{tabular}

The area under the plasma concentration-time curve (AUC), the mean residence time (MRT), the half-life $\left(t_{1 / 2}\right)$, the plasma clearance (CL), the apparent distribution volume $(V)$, and the maximum plasma concentration $\left(C_{\max }\right)$. 
$22.0 \%$. The investigated pharmacokinetics of hapepunine could be used to better understand its pharmacology.

\section{Conclusion}

A sensitive, rapid, and selective UPLC-MS/MS method was developed for the determination of hapepunine in mouse blood, with a linear range of $1-1000 \mathrm{ng} / \mathrm{mL}$ and LLOQ of $1.0 \mathrm{ng} / \mathrm{mL}$, and a needed blood volume of $20 \mu \mathrm{L}$. The sample was prepared by one-step acetonitrile precipitation. This method was successfully applied to study the pharmacokinetics of hapepunine in mice, and the average absolute bioavailability was calculated to be $22.0 \%$.

\section{Conflict of Interest Statement}

The authors declare that there is no conflict of interest regarding the publication of this paper.

\section{References}

1. Cunningham, A. B.; Brinckmann, J. A.; Pei, S. J.; Luo, P.; Schippmann, U.; Long, X.; Bi, Y. F. J. Ethnopharmacol. 2018, 223, 142-151.

2. Wu, X.; Chan, S. W.; Ma, J.; Li, P.; Shaw, P. C.; Lin, G. J. Ethnopharmacol. 2018, 210, 39-46.

3. Zhou, J. L.; Li, P.; Li, H. J.; Jiang, Y.; Ren, M. T.; Liu, Y. J. Chromatogr. A 2008, 1177, 126-137.

4. Lin, B. Q.; Ji, H.; Li, P.; Fang, W.; Jiang, Y. Planta. Med. 2006, 72 ,
5. Qian, Z. Z.; Nohara, T. Phytochemistry 1995, 40, 979-981.

6. Li, S. P.; Cheng, X. M.; Wang, C. H. J. Ethnopharmacol. 2017, 203 , $127-162$.

7. Cheng, H. S.; Ton, S. H.; Kadir, K. A. Phytochem. Rev. 2017, 16, 159-193.

8. Shao, L. J.; Jin, Y.; Fu, H. Y.; Ma, J. S.; Wang, X. Q.; Jin, Y. X.; Wen,

C. C. J. Anal. Methods Chem. 2018, $2018,9412708$.

9. Geng, P.; Luo, J.; Weng, Z.; Fan, Z.; Zhang, B.; Ma, J.; Wang, X.; Zhang, M. Biomed. Chromatogr. 2018, 32, e4273.

10. Chen, L. G.; Zhang, B.; Liu, J. L.; Fan, Z. H.; Weng, Z. W.; Geng, P. W.; Wang, X. Q.; Lin, G. Y. BioMed Res. Int. 2018, 2018, 1578643.

11. Ma, J; Wang, S.; Huang, X.; Geng, P.; Wen, C.; Zhou, Y.; Yu, L.; Wang, X. J. Pharm. Biomed. Anal. 2015, 111, 131-137.

12. Zhang, Q. W.; Wen, C. C.; Xiang, Z.; Ma, J. S.; Wang, X. Q. J. Pharm. Biomed. Anal. 2014, 90, 134-138.

13. Zhou, Y. F.; Chen, B. B.; Chen, J. Y.; Dong, Y. W.; Wang, S. H.; Wen,

C. C.; Wang, X. Q.; Yu, X. M. Acta Chromatogr. 2018, 30, 131-135.

14. Wang, S. H.; Lin, Z. X.; Su, K.; Zhang, J.; Zhang, L. J.; Gao, Z. M.; Wang, Z. Y.; Ma, J. S.; Wang, X. Q. Acta Chromatogr. 2018, 30, $26-30$.

15. Wei, Z.; Ye, L. X.; Jiang, Y. Y.; Zhang, Z. G.; Wang, X. Q. Lat. Am. J. Pharm. 2018, 37, 523-528.

16. Zhang, Q.; Wen, C.; Xiang, Z.; Ma, J.; Wang, X. J. Pharm. Biomed. Anal. 2014, 90, 134-138.

17. Jin, Y. X.; Song, C. C.; Shao, L. J.; Wang, L. T.; Tu, X. T.; Chen, B. B.; Chen, J. Y.; Zhi, Y. H.; Wen, C. C.; Zhu, W. Z. Lat. Am. J. Pharm 2017, 36, 1204-1209.

18. Wang, Y.; Lin, Z. X.; Wang, Q. Q.; Su, K.; Wen, C. C.; Zeng, M.; Wang, X. C. Lat. Am. J. Pharm. 2017, 36, 553-556.

19. Geng, P. W.; Zhang, J.; Chen, B. B.; Wang, Q. Q.; Wang, S. H.; Wen, C. C. Acta Chromatogr. 2018, 30, 136-140.

20. Chen, L. G.; You, W. W.; Chen, D. W.; Cai, Y.; Wang, X. Q.; Wen, C. C.; Wu, B. BioMed Res. Int. 2018, 2018, 6562309.

21. Xiong, J. H.; Ye, H.; Lin, Y. X.; Yang, J. Z.; Chen, D. W.; Yu, D. G.; Chen, L. G. Curr. Pharm. Anal. 2017, 13, 340-344.

22. Lin, Y. X.; Pan, P. P.; Chen, L. G.; Yang, J. Z.; Chen, D. W.; Wang, S. J.; Xiong, J. H. Curr. Pharm. Anal. 2016, 12, 296-299. 